\title{
Democracy and Government Performance: Holding Incumbents Accountable in English Local Governments*
}

\author{
George A. Boyne Cardiff University \\ Oliver James University of Exeter \\ Peter John University of Manchester \\ Nicolai Petrovsky Cardiff University
}

\begin{abstract}
The link between government performance and support for incumbents is a key mechanism of accountable government. We model the vote share of incumbent administrations in local government as proportional and nonproportional responses to public service performance. We evaluate the models using a panel data set covering performance and elections from 2001 to 2007 in English local governments where an incumbent party or coalition was up for reelection. We control for the previous vote, whether the incumbent administration is of the national governing party, and local economic conditions. We find evidence for a nonproportional, performance threshold hypothesis, which implies that voters' behavior is affected by clear gradations of performance. Only the difference between low performance and at least mediocre performance matters. There is no reward for high performance. Instead our findings suggest negativity bias in the relationship between performance and electoral support for incumbents.
\end{abstract}

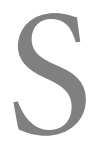
tudies of economic voting have long found that, depending on context, incumbents are often held responsible for macro-economic performance and are rewarded or punished accordingly (e.g., Dorussen and Taylor 2002; Duch and Stevenson 2006; van der Brug, van der Eijk, and Franklin 2007). Just as citizens encounter economic outcomes, it is increasingly recognized that they evaluate many other aspects of government performance that affect their lives, such as providing education, allocating welfare, and maintaining the environment. With citizens paying higher attention to valence (Clarke et al. 2004) and less attention to ideological distance, punishment and reward for service performance would seem to be an increasingly important element of vote choice.

Extant studies of performance evaluation focus on the national level (Bartle 2003; Johnston and Pattie 2001), but government services are often provided, experienced, and consumed in local environments where local politicians and bureaucrats make decisions about their quality. There have been few studies of performance evaluation in local contests and, more generally, little research on retrospective voting in local elections. ${ }^{1}$ Exceptions are school board elections in the United States where there is support for performance voting (Berry and Howell 2007) and U.S. suburban administrations where voters who view performance positively are less likely to support challengers to incumbents (Oliver and Ha 2007, 401-02).

We analyze the form of the relationship between local public service performance and electoral support for local incumbents. In contrast to the economy where a few headline measures, notably inflation and unemployment, dominate debate, government services have multiple measures of performance, ranging from crime rates and school performance league tables to measures of bureaucratic efficiency. But England uniquely has an official categorization of local service performance according to five broad,

${ }^{\star}$ Author order is alphabetical: all make an equal contribution to the article.

${ }^{1}$ Berry and Howell $(2007,845)$ find that fewer than $1 \%$ of 212 articles on elections in leading U.S. political science journals address local elections, and none address retrospective voting.

The Journal of Politics, Vol. 71, No. 4, October 2009, Pp. 1273-1284

doi:10.1017/S0022381609990089

(C) 2009 Southern Political Science Association

ISSN 0022-3816 
summary scores from poor to excellent service provision that can give a signal to voters. So we can ask: Do local electorates respond to fine-grained continuous governmental assessments of performance or citizen perceptions in a linear way? Do electorates respond to summary scores that provide categorization according to the level of performance? Are there performance threshold effects? Is there evidence of positivity or negativity bias?

To address these questions, we use the case of English local government which presents a tough test for theories of performance voting because, unlike most U.S. local elections, party labels are very important. Local elections are, to an extent, opinion polls on national incumbents, which make them secondorder elections, linked to what is going on in the national contest (Miller 1988; Rallings, Thrasher, and Denver 2005; Reif and Schmitt 1980). If performance voting is still found in this context, it is a phenomenon potentially of broad relevance. We assess proportional and nonproportional specifications using aggregate data to estimate the percentage of the vote for the incumbent administration. In a proportional model, incumbent electoral support is positively and linearly related to performance, whereas in a nonproportional model electoral support only changes in response to large changes or deteriorations. Given the importance of unobserved heterogeneity across government units and the possible bias this may introduce, we use panel data for multiple elections rather than modeling each round of elections separately (Berry and Howell 2007).

\section{Theories of Performance and Support for Elected Incumbents}

The allocation of responsibility for policymaking is increasingly noted as an influence on electors' responses to policy, including economic, outcomes (Anderson 2000; Stein 1990). It is often hard for citizens to observe accurately the marginal adjustments in the aggregates of employment, inflation, and economic activity that result from the policy instruments of particular governments rather than other sources. By contrast, electors might take more account of local service performance in local elections where the responsible public bureaucracies are under direct control by politicians and are engaged in a much more limited range of activities than national, regional, or state governments. In this article we analyze the relationship between performance and electoral support for local incumbents over time. We examine which form of performance has a relationship with support for incumbents, distinguishing between governmental perceptions of performance as captured in managerial indicators and citizen perceptions of performance as measured by the satisfaction with overall services provided. Satisfaction measures are influenced by, amongst other factors, perceived performance of government services and expectations as revealed by sample surveys of satisfaction with services and can differ greatly from managerial measures (James 2009; Stipak 1980; Van Ryzin et al. 2004). Our research helps shed light on what kind of performance measure has electoral ramifications.

We examine performance and incumbents' electoral support in two sets of models. First, the proportional or linear response to performance model suggests a continuous relationship between performance and support for incumbents, with electors watching carefully the actions of the governed, and voting accordingly when the opportunity comes. This linear specification is similar to the thermostatic model of the opinion-policy relationship that suggests voters examine the difference between the level of policy provided by government and their preferred level (Soroka and Wlezien 2005; Wlezien 1995).

Second, the nonproportional response to performance models draw on research suggesting that electorates do not respond to potential stimuli, notably changes in economic conditions, in a linear way. One strand of work suggests that this is because voters are often not well informed about policy issues and may not notice fine-grained differences (Anderson 2000; Delli Carpini and Keeter 1996). Previous research on English local government has shown that the introduction of a performance information system providing local voters with a simple summary of the level of each government's performance acted as a shock to incumbent support in the following local election. Armed with the new public performance information, voters exhibited negativity bias, punishing the poor performing incumbents but not giving equivalent reward to top performers (James and John 2007). The analysis presented here extends this insight to assess the relationship between levels of performance and electoral support over time, examining whether performance matters only when certain threshold levels of performance are crossed, and examining nonproportionality in terms of whether only relatively large increases or declines in performance matter.

We adopt a conditional approach common in recent studies of economic voting that find context alters the relationships between economic variables 
and election outcomes (Lewis-Beck and Paldam 2000). The competitiveness of the election is potentially important: higher competitiveness could strengthen the relationship between performance and electoral support. Under the condition of high competition the local opposition becomes a viable alternative to the incumbent administration whereas under low competition the incumbent does not face such a risk. In addition, the news media influence the reporting of performance information as shown in U.S. school board elections (Berry and Howell 2007). We examine the tone of local media coverage of performance as a moderating influence. Developing the approach of James and John (2007), we suggest voters react to the extent the media report net positive news stories about performance.

We consider other factors likely to be important influences on incumbent support: local economic conditions and fiscal performance measured by the level of local taxes. Research on the U.S. federal system suggests that voters attribute state-level economic conditions to decisions by national politicians rather than their state governor (Stein 1990). Johnston et al. (2000) show that local economic conditions affect incumbent evaluation for national elections in England and Wales, which further suggests national rather than local attribution of responsibility. Nevertheless, since local government has some influence on the local economy, we include local economic performance as a potential influence on the electoral support for an incumbent administration. We also include local property values. Fischel (2001) argues that the fate of local incumbents in the United States depends in part on whether homes maintain their value. Local electorates tend to reject policies that lead to reductions in the value of property. Since England has a high rate of homeownership, we expect the same relationship.

Fiscal performance has been noted as an influence on voting in state and local, as well as national, contexts. Niemi, Stanley, and Vogel (1995) and Lowry, Alt, and Ferree (1998) find that voters hold U.S. governors to account for the level of state taxes, although the evidence is not clear cut (Glaser and Hildreth 1996). Martinussen (2004) finds support for local economic and fiscal voting in Norway. In England, some argue that voters punish government with high taxation rates while others claim that the public has a redistributionalist point of view (Hall and Preston 2000). Also, grants from central to local government mainly determine local tax rates because they take up $75 \%$ of local revenue, weakening local fiscal accountability. However, Gibson has challenged the conventional wisdom that local taxes do not affect voting behavior (Gibson 1988, 1994). We examine evidence relevant to this argument.

The English local elections are not fully distinct from broader national politics, and local incumbent parties' electoral support is influenced by national factors (Miller 1988). While the local parties have a high degree of autonomy, such as over the selection of candidates, they run under the banner and authority of the national party organization. Given the prominence of national issues, voters' opinions about national government have strong effects on their support for local incumbent administrations, with unpopularity conventionally seen as having a negative impact on the local party if it is the same as that of the national incumbent, and a positive impact if not. Even though local elections are second order, having a lower level of importance than national contests, voters are still capable of making judgments about the local incumbent administrations (Rallings and Thrasher 1997). Similar to the controversy about local economic voting, this dispute is also addressed by our data.

\section{Methods and Data}

The best way to test the relationship between public service performance and electoral choice is with data from successive time periods. It is rare to find such cases because performance management systems are temporary and succeed each other with bewildering regularity. Yet local government in England has the same performance data for its units over a reasonably long time period, providing some unique advantages for our study. Since 2002 there has been a publicly available officially assessed measure of performance for each local government: the Comprehensive Performance Assessment (CPA) issued by the Audit Commission, an independent monitoring body. The CPA summarizes an array of performance measures into five broad-based scores ranging from a zero- to a four-star rating (Audit Commission 2002; Broadbent 2003)..$^{2}$

Moreover, English local governments exclusively provide a set of nationally prescribed local services and little else. The overwhelming majority of expenditure is on mandated services, and there are statutory limitations and financial disincentives to providing other services. The local electoral system is first-past-the-post,

\footnotetext{
${ }^{2}$ These five categories were formerly known as poor, weak, fair, good, and excellent.
} 
where the vote for candidates from each political party within each electoral district or ward is clear. These features promote a strong link between voting and rewarding or punishing incumbent administrations because there is usually one party in control.

\section{Data and Variables}

Our data are from upper-tier local governments (London boroughs, metropolitan districts, shire counties, and unitary authorities), which are responsible for education, social services, regulatory services (such as land use planning and waste management), housing, libraries, leisure services, and welfare benefits. Data have been collected from Local Election Handbooks (Rallings and Thrasher, 2000-07), the BBC local elections coverage, the "Political Control in Great Britain" maps issued by the consultancy PPS, the Audit Commission, the Office of National Statistics, and the Department of Communities and Local Government.

Our dependent variable is the electoral support for the incumbent administration expressed as a percentage of the total vote. In the case of councils that were controlled by a single party in the year before the election under consideration, this variable contains the vote share of that party. For councils that were controlled by a coalition of two or more parties in the year before the election under consideration, this variable contains the sum of the vote shares of those major parties (Labour, Conservative and Liberal Democrat) involved in the coalition in the year before. We chose to look at electoral support for the incumbent administration rather than whether or not the incumbent administration was reelected because the latter would only be an indirect indicator of electoral judgment on the incumbent administration. This is due to the electoral system, which frequently produces a substantial divergence between the vote share of a party and the seat share it wins on the council (Rallings and Thrasher 1997, 110-15).

We use three measures of performance. The first indicator is the service performance score, a summary measure of performance theoretically ranging from 0 (worst) to 100 (best). It is based on a range of managerial performance information, including Best Value Performance Indicators, which the law requires each local authority to provide, and covers all major public services (e.g., education, housing, social services, transport, planning, waste collection) and encompasses dimensions of performance such as service quantity, quality, and effectiveness. The Audit Commission carries out checks of the accuracy of these indicators. Our second indicator is the Comprehensive Performance Assessment (CPA). The CPA is derived in equal parts from the service performance score and judgments by Audit Commission inspectors on a local government's ability to improve, forming a summary rating of a local government's performance. In other words, the CPA envelops the service performance score. The five levels of the rating are: zero stars, one star, two stars, three stars, and four stars. Our CPA measure is made up of two dummy variables: the first representing a CPA rating of two stars and the second representing a CPA rating of three stars or four stars. The two lowest CPA ratings, zero stars and one star, form the base (left out) category. Finally, for citizen perceptions of performance, we use the percentage of citizens stating that they are satisfied or very satisfied with the overall services provided by their local government. These data are also nationally mandated and are gathered from large random sample surveys carried out every three years. The Audit Commission then independently verifies the reliability of these data. Our indicator is based on the three waves of the survey carried out in 2000-01, 2003-04, and 2006-07. All performance indicators are lagged by one year ${ }^{3}$ as they are generally collected later in the year than elections take place, and in the case of the CPA-the one performance measure easily available to the general public-published toward the end of a calendar year, more than half a year later than elections take place.

We use the vote share of the current incumbent party or coalition in the last election to control for persistence of political support because there is likely to be a fraction of voters with strong partisanship in every council. In the case of councils that were controlled by a single party in the year before the election under consideration, this variable contains the vote share of that party in the election preceding the election under consideration. In the case of councils that were controlled by a coalition of two or more parties in the year before the election under consideration, this variable contains the sum of the vote shares of those major parties (Labour, Conservatives, Liberal Democrats) involved in the coalition. This measure is not equivalent to a lagged dependent variable because the current incumbent party or coalition in many cases (27 council-years in the proportional and threshold models reported in Tables 1 and 2)

\footnotetext{
${ }^{3}$ Since there are only three waves of the aggregate citizen satisfaction indicator, it is lagged one year if there was an election in the next year, otherwise two or three years, depending on when the next election was held.
} 
was not the incumbent previously but was in the opposition. As a result, this variable does not suffer from the bias associated with using lagged dependent variables in fixed-effects models.

We introduce a number of control variables to exclude some alternative explanations for how well the incumbent administration does at the polls. First, since the local elections in England are second order to the national system, we control for the effect of a local incumbent party also governing nationally by including a dummy variable to indicate Labour councils. Further, we also create a dummy variable to indicate Liberal Democrat councils, as this party is the perennial opposition party of British national politics and sometimes benefits locally when the national government is held in low esteem while at other times Liberal Democrat councils may be punished for the unpopularity of their national party.
We control for characteristics of the local elections that may affect the performance/incumbent support relationship. We include a dummy variable for whole council elections (as opposed to elections by thirds) to take into account the difference in the perceived importance of these elections to votersespecially since voters will feel they are more likely to achieve a change in political control when all the councilors are up for election rather than just a third of them. Some elections are more competitive than others, as a party may enjoy a comfortable majority in one council but barely maintain control in another. We therefore include the closeness of the last election as an explanatory variable. Closeness is defined as the percentage point difference between the vote share of the party gaining the largest number of votes and the vote share of the party gaining the second largest number of votes.

\section{TABle 1 Explaining Vote Share of the Incumbent Administration by Service Performance Score-Proportional and Positivity vs. Negativity Models}

\begin{tabular}{|c|c|c|}
\hline & $\begin{array}{l}\text { Proportional } \\
\text { model }\end{array}$ & $\begin{array}{l}\text { Positivity vs. } \\
\text { negativity model }\end{array}$ \\
\hline Service performance score before the election & $0.018(0.065)$ & \\
\hline $\begin{array}{l}\text { Service performance score increased by } 1 / 3 \text { std. deviation } \\
\text { or more before the election }\end{array}$ & & $1.202(0.923)$ \\
\hline $\begin{array}{l}\text { Service performance score declined by } 1 / 3 \text { std. deviation } \\
\text { or more before the election }\end{array}$ & & $1.184(1.059)$ \\
\hline $\begin{array}{l}\text { Competitiveness: difference in vote share of two biggest } \\
\text { parties in the last election }\end{array}$ & $-0.130(0.062)^{\star \star}$ & $-0.261(0.067)^{\star * \star}$ \\
\hline$\%$ support for current incumbent in the previous election & $0.819(0.080)^{\star * *}$ & $0.747(0.100)^{* * *}$ \\
\hline Labour (national governing party) incumbent (dummy) & $-2.791(1.227)^{\star \star}$ & $-4.770(1.723)^{\star * \star}$ \\
\hline Liberal Democratic incumbent (dummy) & $-3.616(1.658)^{\star *}$ & $-0.017(2.270)$ \\
\hline Whole-council election (dummy) & $-7.635(2.157)^{\star * *}$ & $-0.907(4.216)$ \\
\hline Average first-quarter claimant rate & $-1.991(1.236)$ & $-1.274(1.982)$ \\
\hline $\begin{array}{l}\text { Average home price in the financial year before the election } \\
\quad \text { (in } \mathfrak{E} 1,000)\end{array}$ & $-0.064(0.086)$ & $0.152(0.130)$ \\
\hline Average council tax/dwelling (in $\mathfrak{E}$ ) & $-0.009(0.016)$ & $-0.016(0.029)$ \\
\hline Year dummy for 2004 & $3.212(2.729)$ & \\
\hline Year dummy for 2005 & $8.279(3.255)^{\star *}$ & $9.684(5.276)^{\star}$ \\
\hline Year dummy for 2006 & $4.894(4.111)$ & $-0.090(6.431)$ \\
\hline Year dummy for 2007 & $5.454(4.967)$ & $-0.958(7.423)$ \\
\hline Constant & $30.726(17.474)^{\star}$ & $4.469(26.939)$ \\
\hline Observations & 276 & 212 \\
\hline Number of local governments & 134 & 131 \\
\hline F-test of H0: "The model explains nothing" & $p<.0001$ & $p<.0001$ \\
\hline $\mathrm{R}^{2}$ within & .67 & .68 \\
\hline $\mathrm{R}^{2}$ between & .19 & .19 \\
\hline $\mathrm{R}^{2}$ overall & .32 & .17 \\
\hline
\end{tabular}

Fixed effects results with Huber-White standard errors adjusted for clustering on each local government in parentheses. Note that the coefficient on the constant term reflects the average local government fixed effect plus all idiosyncrasies of the 2003 election in case of the proportional model and the 2004 election in case of the positivity vs. negativity model.

${ }^{\star}$ significant at $10 \% ;{ }^{\star *}$ significant at $5 \% ;{ }^{\star * *}$ significant at $1 \%$. 
TABLE 2 Explaining Vote Share of the Incumbent Administration by the Comprehensive Performance Assessment (CPA) Grades-Threshold and Positivity vs. Negativity Models

\begin{tabular}{|c|c|c|c|}
\hline & \multicolumn{2}{|c|}{ Threshold model } & \multirow[b]{2}{*}{$\begin{array}{c}\text { Positivity vs. } \\
\text { negativity model }\end{array}$} \\
\hline & $\begin{array}{c}\text { Reward } \\
\text { formulation }\end{array}$ & $\begin{array}{l}\text { Extremes } \\
\text { formulation }\end{array}$ & \\
\hline $\begin{array}{l}\text { Mediocre performance before the election: } \\
\text { CPA } 2 \text { stars (dummy) }\end{array}$ & $3.401(1.188)^{* * *}$ & & \\
\hline $\begin{array}{l}\text { High performance before the election: } \\
\text { CPA } 3 \text { or } 4 \text { stars (dummy) }\end{array}$ & $3.879(1.689)^{\star \star}$ & $0.478(1.100)$ & \\
\hline $\begin{array}{l}\text { Low performance before the election: } \\
\text { CPA } 0 \text { or } 1 \text { stars (dummy) }\end{array}$ & & $-3.401(1.188)^{\star \star \star}$ & \\
\hline $\mathrm{CPA}$ improvement (dummy) & & & $-0.500(0.845)$ \\
\hline $\mathrm{CPA}$ worsening (dummy) & & & $-2.291(1.350)^{\star}$ \\
\hline $\begin{array}{l}\text { Competitiveness: difference in vote share } \\
\text { of two biggest parties in the last election }\end{array}$ & $-0.132(0.055)^{\star \star}$ & $-0.132(0.055)^{\star \star}$ & $-0.251(0.065)^{\star * *}$ \\
\hline $\begin{array}{l}\% \text { support for current incumbent in the } \\
\text { previous election }\end{array}$ & $0.828(0.079)^{\star * *}$ & $0.828(0.079)^{\star * *}$ & $0.787(0.098)^{\star \star \star *}$ \\
\hline $\begin{array}{l}\text { Labour (national governing party) } \\
\text { incumbent (dummy) }\end{array}$ & $-2.830(1.235)^{\star \star}$ & $-2.830(1.235)^{\star \star}$ & $-3.690(1.829)^{\star *}$ \\
\hline Liberal Democratic incumbent (dummy) & $-3.526(1.803)^{\star}$ & $-3.526(1.803)^{\star}$ & $0.967(2.341)$ \\
\hline Whole-council election (dummy) & $-7.116(2.119)^{\star * *}$ & $-7.116(2.119)^{\star * *}$ & $-2.010(4.057)$ \\
\hline Average first-quarter claimant rate & $-2.692(1.263)^{\star \star}$ & $-2.692(1.263)^{\star \star}$ & $-1.567(2.137)$ \\
\hline $\begin{array}{l}\text { Average home price in the financial year } \\
\text { before the election (in } \mathfrak{E} 1,000 \text { ) }\end{array}$ & $-0.069(0.073)$ & $-0.069(0.073)$ & $0.152(0.141)$ \\
\hline Average council tax/dwelling (in $\mathfrak{E}$ ) & $-0.008(0.014)$ & $-0.008(0.014)$ & $-0.016(0.026)$ \\
\hline Year dummy for 2004 & $2.450(2.587)$ & $2.450(2.587)$ & \\
\hline Year dummy for 2005 & $7.473(2.878)^{\star \star}$ & $7.473(2.878)^{\star \star}$ & $6.586(5.341)$ \\
\hline Year dummy for 2006 & $4.182(3.461)$ & $4.182(3.461)$ & $-0.323(6.471)$ \\
\hline Year dummy for 2007 & $4.607(4.089)$ & $4.607(4.089)$ & $-1.640(7.482)$ \\
\hline Constant & $30.552(15.597)^{\star}$ & $33.953(15.755)^{\star \star}$ & $5.672(27.449)$ \\
\hline Observations & 276 & 276 & 212 \\
\hline Number of local governments & 134 & 134 & 131 \\
\hline F-test of H0: "The model explains nothing" & $p<.0001$ & $p<.0001$ & $p<.0001$ \\
\hline $\mathrm{R}^{2}$ within & .69 & .69 & .69 \\
\hline $\mathrm{R}^{2}$ between & .17 & .17 & .19 \\
\hline $\mathrm{R}^{2}$ overall & .31 & .31 & .19 \\
\hline
\end{tabular}

Fixed effects results with Huber-White standard errors adjusted for clustering on each local government in parentheses. Note that the coefficient on the constant term reflects the average local government fixed effect plus all idiosyncrasies of the 2003 election in case of the threshold model and the 2004 election in case of the positivity vs. negativity model.

${ }^{*}$ significant at $10 \% ;{ }^{* *}$ significant at $5 \%$; ${ }^{* *}$ significant at $1 \%$.

We further control for factors other than public service performance that may affect voters' judgments. Following the economic voting literature and to capture general economic conditions, we use the percentage of the working-age population claiming job seekers' allowance (the claimant rate) in the first quarter of an election year. This variable comes from the United Kingdom Office of National Statistics, from which we obtained the claimant rates for January, February, and March of each year and then took their mean. We use data on the first quarter because it precedes the election and voters should be most attentive to the economic situation they recently encountered. This variable is a proxy for the unemployment rate, which is not collected annually at the local government level. It is a very good proxy: the correlation between the unemployment rate at local government level from the 2001 census with the claimant rate for the first quarter of that year (our indicator) is .96 ( $92 \%$ of the variance in the claimant rate is explained by the unemployment rate).

To test whether the 'Homevoter Hypothesis' (Fischel 2001) - the theoretical argument that local incumbent administration's fate depends to a significant part on whether homes maintain their value- 
holds in England, we include the average value of all homes sold in the local government's jurisdiction in the financial year (April 1-March 31) immediately preceding the election (held in May or June). This variable comes from the U.K. Land Registry, a governmental agency that maintains title records, including sale prices, on all properties in the country.

We control for the level of tax levied by the local government. We include the average council tax per dwelling (in $\mathfrak{E}$ ) from the election year as an explanatory variable. Council tax rates for the election year are known well in advance before the election takes place. The hypothesis is that electors will punish relatively high levels of council tax (Brender 2003).

\section{Model Specification}

We estimate models to evaluate different conceptualizations of the relationship between performance and support for the incumbent administration. Our interest in incumbent support means that councils that are not under any party's control in any of the years covered by our data (as is the case in 9 out of 148 local governments) are not included. All our specifications are variations of the following generic model:

$$
\begin{aligned}
\text { Electoral support }_{\mathrm{it}}= & \beta f(\text { perform } .)_{\mathrm{i}, \mathrm{t}-1} \\
& + \text { other factors }+ \text { random shocks }
\end{aligned}
$$

In other words, we explain the incumbent administration's electoral support as a function of public service performance as well as other observed and unobserved factors and random shocks. The subscript $i$ stands for the local government and the subscript $t$ stands for the year, where $t-1$ indicates a one-year lag. Finally, and most importantly, performance enters the equation inside an unspecified function $f()$, which means that it can do so in any way, linearly or not and with or without thresholds. The core hypothesis of this article is that $\beta$ is not zero-in other words, that public service performance matters in some way for how the incumbent administration fares at the polls.

\section{Proportional Response to Performance Model}

For the proportional response to performance model, the sets of performance variables discussed thus far are simply entered linearly into the specification:

$$
\begin{aligned}
\text { Electoral support }_{\mathrm{it}}= & \beta \text { perform }_{\cdot \mathrm{i}, \mathrm{t}-1}+\text { other factors } \\
& + \text { random shocks }^{\text {randor }}
\end{aligned}
$$

\section{Nonproportional Response to Performance Models}

For the nonproportional response to performance models, we create variations of the sets of performance variables discussed thus far. Performance could affect support for the incumbent administration in a nonproportional way if only relatively large increases or declines in performance matter, or if performance matters only when a threshold is crossed. We now discuss both of these possibilities.

\section{Positivity Bias versus Negativity Bias}

In this version of the nonproportional model, electors do not react to small changes of performance but to relatively large jumps. This model allows us to test for evidence of negativity bias, i.e., the electorate placing a larger weight on negative rather than positive information (Lau 1982, 1985; Soroka 2006). The equation looks rather similar to the proportional response model, namely:

$$
\begin{aligned}
\text { Electoral support }_{\mathrm{it}}= & \beta_{1} \text { large perform.increase } \mathrm{e}_{\mathrm{i}, \mathrm{t}-1} \\
& +\beta_{2} \text { large perform.decrease } \mathrm{i}_{\mathrm{i}, \mathrm{t}-1} \\
& + \text { other factors } \\
& + \text { random shocks }
\end{aligned}
$$

but the twist lies in the new terms large performance increase and decrease, which we define as dummy variables:

Large perform.increase $\mathrm{i}_{\mathrm{i}, \mathrm{t}-1} \equiv$

$$
\left\{\begin{array}{c}
1 \text { if } \Delta \text { perform }_{\cdot \mathrm{i}, \mathrm{t}-1}>\delta s d\left(\text { perform }_{\cdot \mathrm{i}}\right) \\
0 \text { otherwise }
\end{array}\right.
$$

and Large perform.decrease $\mathrm{i}_{\mathrm{i}, \mathrm{t}-1} \equiv$

$$
\left\{\begin{array}{c}
\left.1 \text { if } \Delta \text { perform }_{\cdot \mathrm{i}, \mathrm{t}-1}<-\delta s d \text { perform }_{\cdot \mathrm{i}}\right) \\
0 \text { otherwise }
\end{array},\right.
$$

where $\Delta$ performance $_{\mathrm{i}, \mathrm{t}-1}$ denotes the first difference (performance $_{\mathrm{i}, \mathrm{t}-1}-$ performance $\left._{\mathrm{i}, \mathrm{t}-2}\right), s d\left(\right.$ performance $\left._{\mathrm{i}}\right)$ denotes the within local government standard deviation of performance, and $\delta>0$ denotes a multiplier that indicates the fraction or multiple of a standard deviation that defines "large." We set $\delta=1 / 3$ because a change of more than one third of a standard deviation in the service performance score is of approximately similar magnitude to a change of one star in the CPA (which differs in having clear categories and 
being based on auditor judgment, not just indicator scores).

\section{Performance Thresholds}

Rather than reacting to change along a continuum of performance, voters may only react if performance exceeds or falls below a certain clearly labeled standard because there needs to be a significant external stimulus to draw attention to the voter of a change in performance whereas they are less likely to notice the small increments that are typical of the proportional model. The performance thresholds hypothesis can be modeled using indicators for different discrete levels of performance.

We test all specifications against data on governmental perceptions of performance. Table 1 contains a test of the proportional and the positivity versus negativity model using the service performance score. Table 2 contains tests of the threshold model and the positivity versus negativity model using the CPA. Citizen perceptions of performance as measured by the satisfaction survey can only be meaningfully be used in the proportional model. Those results are presented in Table 3. All models are estimated using two-way fixed effects. Hausman tests suggest unobserved heterogeneity-likely due to persistent deprivation in some areas and persistent differences between local political cultures (Dorling et al. 2007)—which would induce bias if not removed. By additionally controlling for idiosyncratic shocks in individual years, as for instance the possible effects of the 2005 terrorist attacks on London, the two-way fixed effects model removes an additional source of bias. We now present our findings from all four models.

\section{Findings}

We find support for negativity bias in several specifications. On the other hand, we do not find support for the simple proportional response model, either for the service performance score (Table 1, proportional model) or for citizen satisfaction as measured by the percentage of citizens stating that they are satisfied with their local government's service performance (Table 3).

We find support for the positivity versus negativity bias model for the CPA but not for service performance. Recall that the service performance score is one of the two components going into a CPA rating, the other one being based on the judgments made by the Audit Commission after conducting an inspection of a council. For the CPA, the positivity versus negativity model in Table 2 shows

\section{TABLE 3 Explaining Vote Share of the Incumbent Administration by Citizen Satisfaction}

\begin{tabular}{|c|c|}
\hline & Citizen perceptions model \\
\hline Lag of $\%$ of citizens very/fairly satisfied with the local government's service performance & $0.052(0.056)$ \\
\hline Competitiveness: difference in vote share of two biggest parties in the last election & $-0.233(0.063)^{* * *}$ \\
\hline$\%$ support for current incumbent in the previous election & $0.854(0.083)^{* * *}$ \\
\hline Labour (national governing party) incumbent (dummy) & $0.750(1.452)$ \\
\hline Liberal Democratic incumbent (dummy) & $-6.362(2.700)^{\star \star}$ \\
\hline Whole-council election (dummy) & $-9.535(1.333)^{* * *}$ \\
\hline Average first-quarter claimant rate & $0.717(1.002)$ \\
\hline Average home price in the financial year before the election (in $\mathfrak{E} 1,000$ ) & $0.014(0.027)$ \\
\hline Average council tax/dwelling (in $\mathfrak{E}$ ) & $-0.019(0.008)^{\star \star}$ \\
\hline Year dummy for 2000 & $2.581(2.064)$ \\
\hline Year dummy for 2003 & $1.970(2.192)$ \\
\hline Constant & $21.254(7.268)^{* * *}$ \\
\hline Observations & 297 \\
\hline Number of local governments & 139 \\
\hline F-test of H0: "The model explains nothing" & $p<.0001$ \\
\hline $\mathrm{R}^{2}$ within & .67 \\
\hline $\mathrm{R}^{2}$ between & .31 \\
\hline $\mathrm{R}^{2}$ overall & .43 \\
\hline
\end{tabular}

Fixed effects results with Huber-White standard errors adjusted for clustering on each local government in parentheses. Note that the coefficient on the constant term reflects the average local government fixed effect plus all idiosyncrasies of the 2001 election. ${ }^{\star}$ significant at $10 \% ;{ }^{* *}$ significant at $5 \%$; ${ }^{\star *}$ significant at $1 \%$. 
that a decline by one or more stars is associated with a two percentage point reduction in electoral support for the incumbent administration. As there is no relationship between an increase in the CPA and electoral support for the incumbent at the next election, there is evidence for negativity bias. ${ }^{4}$

The findings also support negativity bias in the threshold model (Table 2). For illustration, we evaluate it in two different formulations. The reward formulation includes dummy variables for mediocre performance (measured by a CPA rating of two stars) and high performance (three stars or four stars). We use it to compare the threshold of mediocre and high performance to the baseline of low performance. In the extremes formulation, on the other hand, we change the baseline to mediocre performance and compare it to dummies for both low (zero stars or one star) and high (three stars or four stars) performance.

In the reward formulation, the incumbent administration in a council that achieves a rating of two stars in the year before the election tends to receive three percentage points more electoral support. In a similar way, councils that are graded three stars or four stars receive almost four percentage points more electoral support. However, it is important to note that there is no statistical difference between the two included categories: the null hypothesis that the coefficients on two stars and three or four stars are equal is not rejected in a joint F-test ( $\mathrm{p}$-value $=.66$ ). This suggests there is no increased reward for councils that have higher CPA ratings than others, but that all are similar in not being in the low-performance group, implying a form of negativity bias. As a robustness check, we also estimated a modified version of the reward formulation, where the base group is made up exclusively of council-years with low performance of zero stars before the election. Since there are very few of those, ${ }^{5}$ we use both zero stars and one star together as the base group.

Similar to the reward formulation, the extremes formulation also provides support for the presence of negativity bias. While being in the low-performance group (zero stars or one star) tends to hit incumbent

\footnotetext{
${ }^{4}$ As a robustness check, we tested whether this finding is moderated by the percentage of citizen stating that they are satisfied with their local government's service performance (the core explanatory variable of the model in Table 3). Yet there is no such interaction. This model only shows a relationship for the CPA, as reported in the threshold model in Table 2.

${ }^{5}$ In our estimation sample, only 13 council-years received a CPA rating of zero stars, and seven of them occurred in 2002.
}

support by three percentage points relative to the base group of mediocre performance (two stars), there is no positive electoral pay-off for those incumbent administrations achieving high performance (three stars or four stars). This finding goes beyond the analysis of James and John (2007) who found negativity bias in the 2003 election following the introductory shock of the new CPA ratings. We show how negativity bias continues to affect performance voting long after its introduction. ${ }^{6}$

The implication of the results from the threshold model is that an incumbent administration only receives a bonus when their local government has received a rating of at least mediocre performance compared to when it received a low rating. Looked at alternatively, incumbent administrations face a reduction in electoral support if local government performance falls to low but do not receive any increase in support if performance increases above mediocrity. Overall our findings suggest that the electorates react to broad levels of performance rather than more finegrained measures.

We examined whether the performance effects were contingent on the tone of news coverage. We reestimated all specifications of the performance models as interactive models, with a net positive news stories score moderating the effect of the performance indicator on the vote share of the incumbent administration. ${ }^{7}$ However, in no case could we reject the null hypothesis of no interaction.

In contrast, electoral competitiveness, as measured by the difference in the vote share of the two largest parties at the last election is associated with slightly lower support for the incumbent administration in all models. This finding suggests that the increasing viability of an alternative incumbent in the local opposition is associated with lower support for incumbents, but that the relationships between nonproportional performance variables and electoral

\footnotetext{
${ }^{6}$ These results also hold in alternative specifications, where all but one of the CPA categories are represented by individual dummy variables. It is for clarity of exposition that we group both the two lowest and the two highest categories together in the two formulations of the threshold model.

${ }^{7} \mathrm{We}$ analyzed the full texts of articles from the "UK National Newspapers" and "UK Regional Newspapers" archives on the LexisNexis Professional database. We found a total of 653 articles discussing individual local governments' CPA grades for each year between the elections covered by our study. We coded each article as either a positive or negative evaluation of the individual local government's performance. Intercoder reliability was .9. We then computed a "net positive stories" score by subtracting the number of negative stories from the number of positive stories.
} 
support are evident even in the presence of this control. ${ }^{8}$ As might be expected, the electoral support for the current incumbent party or coalition persists: every $1 \%$ of the vote share that the incumbent party or coalition gained in the last election translates into around eight-tenth of a percent of the vote share in this election. As this study covers a number of elections (from 2001 in Table 3, and 2002 in Tables 1 and 2, all up to 2007), the electoral fortunes of the national incumbent, Labour, have varied. Yet we do see evidence of punishment of the Labour incumbent in all models bar the citizen perceptions model (Table 3). Liberal Democrats, so far the perennial opposition party of British politics, also receive a punishment in all models but the positivity versus negativity models, which likely reflects their electoral decline in the general election period.

Whole council-elections tend to be associated with seven to ten percentage points less support for the incumbent administration in all but the positivity versus negativity models. This might reflect voters' perceptions of a greater chance of changing the political party control of the local government when all the candidates are up for election. There is only some evidence in accordance with economic voting in the threshold model in Table 2. In all other models, the claimant rate (our proxy for general economic conditions in the local government) is statistically unrelated to electoral support for the incumbent administration. Similarly, average home prices in the financial year immediately preceding an election are statistically unrelated to electoral support. Perhaps voters reason economic conditions are the responsibility of other actors, such as national government, rather than elected local governments. Also, the incumbent administration is not punished for the local tax rate. Only in the citizen perceptions model (Tables 3 ) is it statistically related to slightly lower electoral support for the incumbent administration. The null finding in Tables 1 and 2 is consistent with the largely centrally determined financial regime for the level of local taxes which local voters seem to

\footnotetext{
${ }^{8} \mathrm{We}$ also tried estimating all models as conditional models. First, we augmented them with multiplicative terms testing whether the performance variables are moderated by the closeness of the previous election result (the percentage point difference in votes between the two largest parties), yet only in two cases could the null hypothesis of no interactions be rejected. Second, we augmented them with additive and multiplicative terms testing whether the performance variables are moderated by the percentage of total incumbent seats held by the dominant party in the incumbent coalition, which takes on the value of $100 \%$ in case of a administration controlled by a single party. Only in one case could the null hypothesis of no interactions be rejected.
}

recognize is not primarily the responsibility of the local units.

\section{Conclusions}

The performance of local governments matters for incumbent electoral support. We show this from public authorities' performance scores graded to a comparable standard across local government units. However, the aggregate vote-performance relationship, as in economic voting, does not operate in a straightforward fashion. Thresholds of performance are central to the vote-performance link rather than fine-grained, linear relationships.

Negativity bias exists. Only the difference between low performance and anything better matters and deterioration in performance category is negatively related to support, with no reward for improvement. All the evidence suggests that incumbent administrations do not get a reward for achieving high performance. These asymmetric relationships have implications for the literature on performance based and economic voting, particularly whether incentives promote responsible government. While the opposition becomes relatively more attractive when local governments have low performance, there is no guarantee that new incumbents will greatly improve performance. Future studies, rather than focusing on electorates, may need to take into account the role of opposition as part of a broader analysis of the incentive structures of all the decision makers. Whether incumbent administrations are risk averse with respect to performance because they have few incentives to perform well would be an important part of this analysis.

Finally, behind these findings is the impact of institutional structures, notably for provision of information to voters and the role of electoral systems. Published performance information is increasingly common in the public sector and future research could examine how voters incorporate published performance information in their judgments. In particular, simple summary scores like those in the CPA regime are relatively easily observed by the electorate directly or through the media and are consistent with theories about how voters economize on information (Aidt 2000; James and John 2007; Lupia and McCubbins 1998). However, if local voters only seem to notice bad ratings then publishing information contributes to negativity bias. We were not able to appraise the impact of different electoral systems because these are uniform in English local government. But economic voting studies increasingly stress clarity of responsibility 
as a key factor in performance-based voting (Anderson 2000, 2006; Lewis-Beck and Paldam 2000; Nadeau, Niemi, and Yoshinaka 2002; Powell and Whitten 1993; Sanders 2000; Stein 1990; van der Brug, van der Eijk, and Franklin 2007; Wlezien 2004). The question remains as to whether lessening the clarity of responsibility conventionally argued to exist in the first-pastthe-post majoritarian systems alters the attribution of blame, offering a rich set of opportunities for comparative research.

\section{Acknowledgments}

We thank the Economic and Social Research Council Public Services Programme for support (grant number RES-166-25-0026). Also we thank Rhys Andrews, Susan Banducci, Tony Bertelli, Harold Clarke, John Curtice, Ed Fieldhouse, Janet Grauberg, Christopher Hood, Jeff Karp, Ken Meier, Marianne Stewart, Michael Thrasher, Christopher Wlezien, and the editor and four anonymous reviewers for helpful suggestions.

\section{Manuscript submitted 12 March 2008}

Manuscript accepted for publication 28 December 2008

\section{References}

Aidt, Toke S. 2000. "Economic Voting and Information." Electoral Studies 19 (2-3): 349-62.

Anderson, Cameron. 2006. "Economic Voting and Multilevel Governance: A Comparative Individual-Level Analysis." American Journal of Political Science 50 (2): 449-63.

Anderson, Christopher J. 2000. "Economic Voting and Political Context: A Comparative Perspective." Electoral Studies 19 (2-3): 151-70.

Audit Commission 2002. The Final CPA Assessment Framework for Single Tier and County Councils. London: The Audit Commission.

Bartle, John. 2003. "Partisanship, Performance and Personality: Competing and Complementary Characterizations of the 2001 British General Election.” Party Politics 9 (3): 317-45.

Berry, Christopher R., and William G. Howell. 2007. "Accountability and Local Elections: Rethinking Retrospective Voting." The Journal of Politics 69 (3): 844-58.

Brender, Adi. 2003. "The Effect of Fiscal Performance on Local Government Election Results in Israel: 1989-1998." Journal of Public Economics 87 (9-10): 2187-205.

Broadbent, Jane. 2003. "Comprehensive Performance Assessment: The Crock of Gold at the End of the Rainbow?." Public Money and Management 23 (1): 5-7.

Clarke, Harold D., David Sanders, Marianne C. Stewart, and Paul Whiteley. 2004. Political Choice in Britain. Oxford: Oxford University Press.
Delli Carpini, Michael X., and Scott Keeter. 1996. What Americans Know about Politics and Why It Matters. New Haven, CT: Yale University Press.

Dorling, Daniel, Jan Rigby, Ben Wheeler, Dimitris Ballas, Bethan Thomas, Eldin Fahmy, David Gordon, and Ruth Lupton. 2007. Poverty, Wealth and Place in Britain, 1968 to 2005. Bristol, UK: Policy Press.

Dorussen, Hans, and Michael Taylor. 2002. "Group Economic Voting: A Comparison of the Netherlands and Germany." In Economic Voting, ed. Hans Dorussen and Michael Taylor. London: Routledge, 92-120.

Duch, Raymond M., and Randy Stevenson. 2006. "Assessing the Magnitude of the Economic Vote over Time and Across Nations." Electoral Studies 25 (3): 528-47.

Fischel, William A. 2001. The Homevoter Hypothesis: How Home Values Influence Local Government Taxation, School Finance, and Land-Use Policies. Cambridge, MA: Harvard University Press.

Gibson, J. G. 1988. "Rate Increases and Local Elections: A Different Approach and a Different Conclusion." Policy and Politics 16 (3): 197-208.

Gibson, J. G. 1994. "Voter Reaction to Tax Change: The Case of the Poll Tax." Applied Economics 26 (9): 877-84.

Glaser, Mark A., and W. Bartley Hildreth. 1996. "A Profile of Discontinuity between Citizen Demand and Willingness to Pay Taxes: Comprehensive Planning for Park and Recreation Investment." Public Budgeting and Finance 16 (4): 96-113.

Hall, John, and Ian Preston. 2000. "Tax Price Effects on Attitudes to Hypothecated Tax Increases." Journal of Public Economics 75 (3): 417-38.

James, Oliver. 2009. "Evaluating the Expectations Disconfirmation and Expectations Anchoring Approaches to Citizen Satisfaction with Local Public Services." Journal of Public Administration Research and Theory 19 (1): 107-23.

James, Oliver, and Peter John. 2007. "Public Management at the Ballot Box: Performance Information and Electoral Support for Incumbent English Local Governments." Journal of Public Administration Research and Theory 17 (4): 567-80.

Johnston, Ron, and Charles Pattie. 2001. "Dimensions of Retrospective Voting: Economic Performance, Public Service Standards and Conservative Party Support at the 1997 British General Election." Party Politics 7 (4): 469-90.

Johnston, Ron, Charles Pattie, Daniel Dorling, Iain MacAllister, Helena Tunstall, and David Rossiter 2000. "Local Context, Retrospective Economic Evaluations, and Voting: The 1997 General Election in England and Wales." Political Behavior 22 (2): 121-43.

Lau, Richard R. 1982. "Negativity in Political Perception." Political Behavior 4 (4): 353-78.

Lau, Richard R. 1985. "Two Explanations for Negativity Effects in Political Behaviour.” American Journal of Political Science 29 (1): 119-38.

Lewis-Beck, Michael S., and Martin Paldam. 2000. "Economic Voting: An Introduction." Electoral Studies 19 (2-3): 113-21.

Lowry, Robert C., James E. Alt, and Karen E. Ferree. 1998. "Fiscal Policy Outcomes and Electoral Accountability in the American States." American Political Science Review 92 (4): 759-74.

Lupia, Arthur, and Mathew D. McCubbins. 1998. The Democratic Dilemma: Can Citizens Learn What They Really Need to Know? Cambridge: Cambridge University Press.

Martinussen, Pål E. 2004. "Government Performance and Political Accountability at Subnational Level: The Electoral Fate of 
Local Incumbents in Norway." Scandinavian Political Studies 27 (3): 227-59.

Miller, William L. 1988. Irrelevant Elections? The Quality of Local Democracy in Britain. Oxford: Clarendon Press.

Nadeau, Richard, Richard G. Niemi, and Antoine Yoshinaka. 2002. "A Cross-National Analysis of Economic Voting: Taking Account of the Political Context across Time and Nations." Electoral Studies 21 (3): 403-23.

Niemi, Richard G., Harold W. Stanley, and Ronald J. Vogel. 1995. "State Economies and State Taxes: Do Voters Hold Governors Accountable." American Journal of Political Science 39 (4): 936-57.

Oliver, J. Eric, and Shang E. Ha. 2007. "Vote Choice in Suburban Elections." American Political Science Review 101 (3): 393-408.

Powell, G. Bingham, and Guy D. Whitten. 1993. "A CrossNational Analysis of Economic Voting: Taking Account of the Political Context." American Journal of Political Science 37 (2): 391-414.

Rallings, Colin, and Michael Thrasher. 1997. Local Elections in Britain. London: Routledge.

Rallings, Colin, and Michael Thrasher. 2000-2007. Local Elections Handbook. Plymouth, UK: Local Government Chronicle Elections Centre.

Rallings, Colin, Michael Thrasher, and David Denver. 2005. "Trends in Local Elections in Britain 1975-2003." Local Government Studies 31 (4): 393-413.

Reif, Karlheinz, and Hermann Schmitt. 1980. "Nine Secondorder National Elections - A Conceptual Framework for the Analysis of European Election Results." European Journal of Political Research 8 (1): 3-44.

Sanders, David. 2000. "The Real Economy and the Perceived Economy in Popularity Functions: How Much Do Voters Need to Know? A Study of British Data 1974-97." Electoral Studies 19 (2-3): 275-94.

Soroka, Stuart N. 2006. "Good News and Bad News: Asymmetric Responses to Economic Information." The Journal of Politics 68 (2): 372-85.

Soroka, Stuart N., and Christopher Wlezien. 2005. "OpinionPolicy Dynamics: Public Preferences and Public Expenditure in the United Kingdom.” British Journal of Political Science 35 (4): 665-89.

Stein, Robert M. 1990. "Economic Voting for Governor and U.S. Senator: The Electoral Consequences of Federalism." Journal of Politics 52 (1): 29-53.

Stipak, Brian. 1980. “Local Governments' Use of Citizen Surveys." Public Administration Review 40 (5): 521-25.

van der Brug, Wouter, Cees van der Eijk, and Mark N. Franklin. 2007. The Economy and the Vote: Effects of Economic Conditions on Vote Preferences and Election Outcomes in Fifteen Countries. Oxford: Oxford University Press.

Van Ryzin, Gregg G., Douglas Muzzio, Stephen Immerwahr, Lisa Gulick, and Eve Martinez. 2004. "Drivers and Consequences of Citizen Satisfaction: An Application of the American Customer Satisfaction Index Model to New York City." Public Administration Review 64 (3): 331-41.

Wlezien, Christopher. 1995. "The Public as Thermostat: Dynamics of Preferences for Spending." American Journal of Political Science 39 (4): 981-1000.

Wlezien, Christopher. 2004. "Patterns of Representation: Dynamics of Public Preferences and Public Policy." Journal of Politics 66 (1): 1-20.

George A. Boyne is Professor of Public Sector Management, Cardiff University, Cardiff CF10 3EU, UK.

Oliver James is Professor of Political Science, University of Exeter, Exeter EX4 4QJ, UK.

Peter John is Hallsworth Chair of Governance, University of Manchester, Manchester M13 9PL, UK.

Nicolai Petrovsky is Research Fellow, Cardiff University, Cardiff CF10 3EU, UK. 